\title{
Antibacterial Activity of Extracts from Some Bryophytes
}

\author{
Vizma Nikolajeva $^{1 *}$, Ligita Liepina ${ }^{1}$, Zaiga Petrina ${ }^{1}$, Guntra Krumina ${ }^{1}$, \\ Mara Grube $^{2}$, Indrikis Muiznieks ${ }^{1}$ \\ ${ }^{1}$ Faculty of Biology, University of Latvia, Riga, Latvia \\ ${ }^{2}$ Institute of Microbiology and Biotechnology, University of Latvia, Riga, Latvia \\ Email: *vizma.nikolajeva@lu.lv
}

Received June 25, 2012; revised July 23, 2012; accepted August 4, 2012

\begin{abstract}
The antimicrobial activity of aqueous and ethanolic extracts of 11 Bryophyta species and 9 Marchantiophyta species collected in Latvia was tested against Staphylococcus aureus, Escherichia coli and Bacillus cereus. The extract of Lophocolea heterophylla inhibited the growth of B. cereus, but none of the tested extracts inhibited the growth of $E$. coli. $70 \%$ of bryophyte species demonstrated certain activity in relation to S. aureus. In general, $73 \%$ of ethanolic extracts and 39\% of aqueous extracts exhibited antibacterial activity against S. aureus. The highest degree of antibacterial activity against $S$. aureus was shown by the ethanolic extract of Dicranum scoparium and aqueous extracts of Atrichum undulatum and Rhytidiadelphus squarrosus. The bactericidal action was not ascertained. For the first time antimicrobial activity has been proved for three moss species-Eurhynchium angustirete, Rhytidiadelphus squarrosus and Rhodobryum roseum, and for two liverwort species Frullania dilatata and Lophocolea heterophylla. Qualitative and quantitative differences of plant extracts were evaluated by FT-IR spectra.
\end{abstract}

Keywords: Bryophyta; Marchantiophyta; Antimicrobial Activity

\section{Introduction}

Bryophytes, including liverworts (Marchantiophyta), hornworts (Anthocerotophyta), and mosses (Bryophyta), are a diverse group of land plants that usually colonize habitats with moist or extremely variable conditions. Traditionally, because of their antimicrobial activity, mosses were used as a natural medicine in the Indian culture [1] and as natural diapers [2]. Today, mosses and liverworts are interesting for biotechnological use in medicine, agriculture, and pharmacology $[1,3,4]$. Liverworts have been proposed as ideal models for genetic studies and biotechnological applications [3].

The search for plants with antimicrobial activity has grown in importance in recent years, due to a growing concern about increase in the rate of infection caused by antibiotic-resistant microorganisms. Asakawa $[5,6]$ has analyzed approximately 1000 bryophyte species from the world total of 27,000. However, few studies have been carried out about the antimicrobial properties of European bryophytes. In literature, reports have been found about antibacterial activity of 23 bryophyte species [7-15] that are common in Latvia [16] and other European countries [17-20].

In presented paper, the antimicrobial activity of 20 bryophyte species collected in Latvia was evaluated.

"Corresponding author.

\section{Materials and Methods}

\subsection{Plant Material}

Samples of all tested plants were collected from their native habitats in Salaspils, Kemeri, Iecava and Ropazi (Latvia) in August and September and the specimens were identified. Taxonomic references used were Abolina [16] and Smith [21-23] for liverworts and mosses, and Ignatov and Ignatova [24,25] for mosses. Once harvested, the plant material was maintained in the refrigerator $\left(+4^{\circ} \mathrm{C}\right)$ and processed in five days to obtain extracts.

\subsection{Preparation of the Extracts}

At first, plants were washed with sterile water to remove attached litter, dead material and fragments of epiphytic hosts. One gram of plant material per repetition was finely ground with a pestle and mortar, and then extract was made using $10 \mathrm{ml}$ of sterile water or $50 \%$ ethanol. The suspensions were kept in refrigerator for 18 hours and then centrifuged (Eppendorf, $4000 \mathrm{rpm}, 4^{\circ} \mathrm{C}, 30 \mathrm{~min}$ ). Autoclaved $\left(121^{\circ} \mathrm{C}, 15 \mathrm{~min}\right)$ aqueous extracts were used.

\subsection{Antimicrobial Activity}

Antimicrobial assays were performed on three species of microorganisms maintained in the Microbial Strain Collection of Latvia (MSCL). Following strains were used: 
Bacillus cereus MSCL 330, Escherichia coli MSCL 332 and Staphylococcus aureus MSCL 334. Gentamicin (KRKA, Slovenia) $10 \mathrm{mg} / \mathrm{ml}$ was used as a positive control. For the evaluation of antimicrobial activity two methods were used: the agar-well diffusion method [26] and broth microdilution assay [27]. The tests were performed in triplicates for each microorganism evaluated. The final results were presented as the arithmetic averages.

\subsubsection{Agar-Well Diffusion Method}

Agar diffusion test was performed on Müller-Hinton Agar (Oxoid). Fresh inoculum approximately $10^{6} \mathrm{CFU}$ (colony-forming units) $/ \mathrm{ml}$ of tested microorganisms was used. Aliquots of $70 \mu \mathrm{l}$ of each test-sample solution and control (distilled water and 50\% ethanol) were applied into $6.0 \mathrm{~mm}$ diameter wells. After incubation at $37^{\circ} \mathrm{C} \pm$ $1^{\circ} \mathrm{C}$ for 18 hours the inhibition zone corresponding to the halo formed from well edge to the beginning of the zone of microbial growth was measured.

\subsubsection{Broth Microdilution Assay}

Müller-Hinton Broth (BD Difco ${ }^{\mathrm{TM}}$ ) was used. Test strains were suspended in broth to obtain a final density of approximately $10^{6} \mathrm{CFU} / \mathrm{ml}$. To confirm the initial bacterial counts, serially diluted bacterial cultures were plated on the Müller-Hinton Agar plates and enumerated. The test was performed using three concentrations of each extract $(3 \%, 17 \%$, and $33 \%, v / v)$ in test tubes, including growth (in water or ethanol dilutions) and sterility controls. Tubes were incubated at $37^{\circ} \mathrm{C} \pm 1^{\circ} \mathrm{C}$ for $48 \mathrm{~h}$. After incubation, the mixtures were subjected to successive 10-fold serial dilutions, mixed with a vortex shaker to ensure dispersion and quantitatively cultured in duplicate onto agar plates to determine the number of viable bacteria. Viable cell counts were expressed as CFU/ml and if applicable the minimal inhibitory concentration $\left(\mathrm{MIC}_{80}\right)$ according to Qaiyumi [28] was evaluated.

\subsection{Identification of Chemical Constituents by FT-IR Spectroscopy}

FT-IR absorption spectra of bryophyte extracts were registered on a microplate reader HTS-XT (Bruker, Germany). $50-330 \mu 1$ of each sample were dried on a 96place silicon plate at $<50^{\circ} \mathrm{C}$. Spectra were collected over the wave-number range of $4000-600 \mathrm{~cm}^{-1}, 32$ scans, resolution $4 \mathrm{~cm}^{-1}$. Data were processed with OPUS 6.0 (Bruker, Germany) software. Spectra were Vector normalized and baseline corrected by the rubber-band method.

\subsection{Statistics}

Statistical analysis was done by analysis of variance and by Chi-square $\left(\chi^{2}\right)$ significance test. $P<0.05$ was considered statistically significant.

\section{Results}

The agar-well diffusion method did not show any antibacterial effect of the tested extracts against the investigated microorganisms, and for that reason in subsequent experiments we used the method of broth microdilution assay. Using this method, in many cases significant influence of bryophytes on the growth of microorganisms was found (Table 1). None of the tested bryophyte species (Lophocolea heterophylla, Nowellia curvifolia, Polytrichum commune, Rhodobryum roseum) had a significant influence $(P>0.05)$ on the growth of $E$. coli. The growth of Bacillus cereus was inhibited by the aqueous extracts of L. heterophylla ( $\mathrm{MIC}_{80} 27 \%$ ), and P. commune $\left(\mathrm{MIC}_{80}\right.$ was not achieved) but was not inhibited by the aqueous extracts of $N$. curvifolia and $R$. roseum. The most comprehensive researches have been made about the influence of bryophyte extracts on the growth of Staphylococcus aureus.

\subsection{Antibacterial Activity of Mosses against Staphylococcus aureus}

Of the 12 species, 7 species (58\%) exhibited antimicrobial activity against $S$. aureus (Figure 1). Antibacterial activity against $S$. aureus was not established for Fissidens taxifolius, Hypnum cupressiforme, Plagiomnium undulatum, Pleurozium schreberi and Sphagnum girgensohnii aqueous extracts. On the contrary, H. cupressiforme and S. girgensohnii extracts stimulated the growth of S. aureus (Figure 2).

\subsection{Antibacterial Activity of Liverworts against Staphylococcus aureus}

Of the 8 species, 3 species (38\%) exhibited antimicrobial activity against $S$. aureus (Figure 3). Antibacterial activity against $S$. aureus was not established for Lepidozia reptans, Marchantia polymorpha, Nowellia curvifolia, Plagiochila asplenioides and Radula complanata aqueous extracts. The extract of $N$. curvifolia stimulated the growth of S. aureus (Figure 2).

\subsection{Main Constituents of Bryophytes Extracts}

FT-IR spectra of extracts showed intensive band of $\mathrm{C}=\mathrm{C}$ group at $1600 \mathrm{~cm}^{-1}$ and characteristic stretching bands of $\mathrm{C}=\mathrm{O}$ in $1300-1720 \mathrm{~cm}^{-1}$ region indicating the carbonyl groups of phenolic esters [29], and C-O stretching bands of esters and phenols at 1240 and $1052 \mathrm{~cm}^{-1}$ [30]. The intensities of absorption bands in $1500-1720 \mathrm{~cm}^{-1}$ region varied in different samples thus indicating qualitative and quantitative differences of the biochemical com- 
Table 1. Minimal inhibitory concentration $\left(\mathrm{MIC}_{80}\right)$ of plant extracts (in \%) against Staphylococcus aureus.

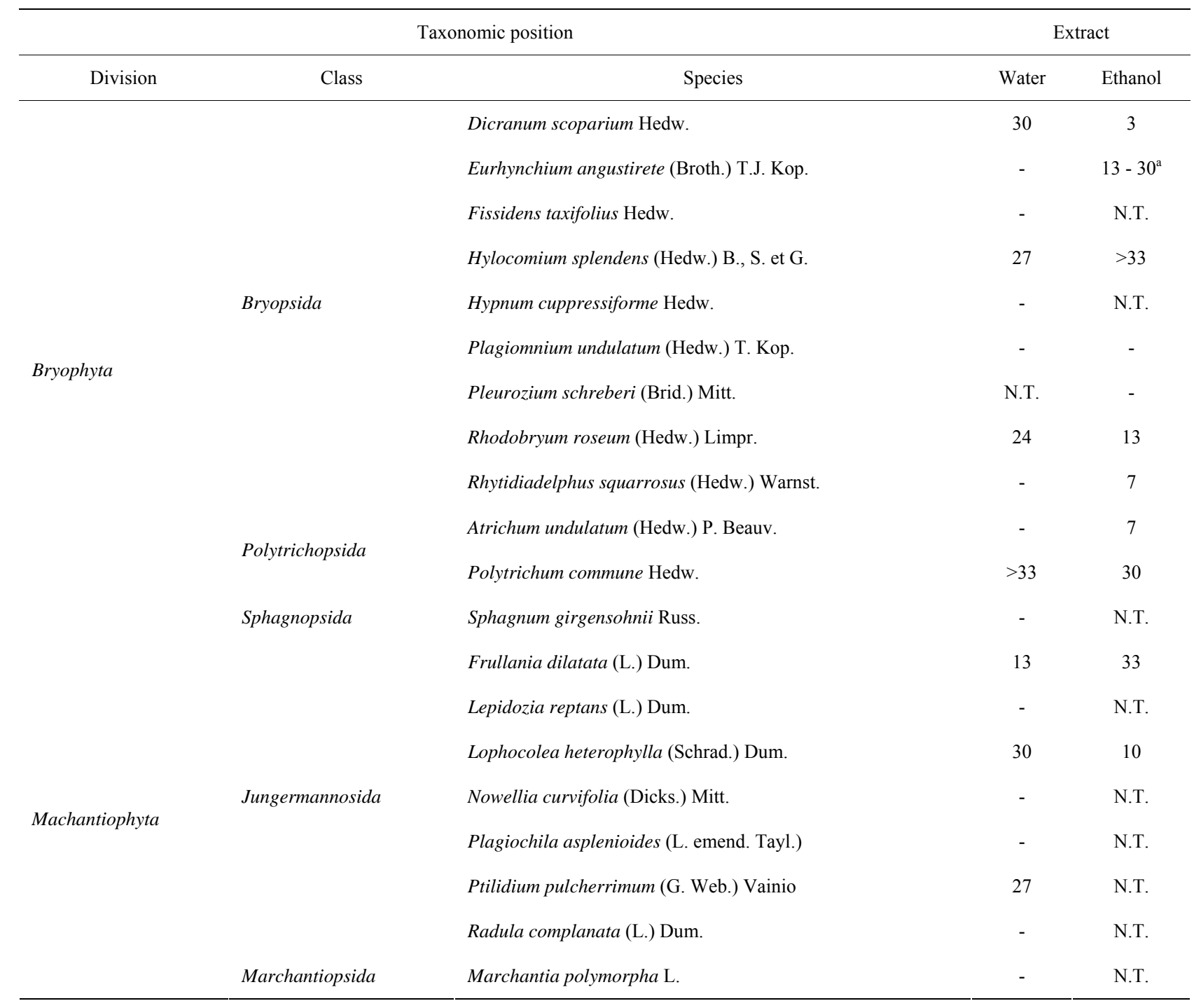

-Did not have $\mathrm{MIC}_{80}$; ${ }^{\mathrm{a}}$ Only in the indicated interval of concentration; N.T. not tested.

position of bryophyte extracts depending on the extraction method and species (Figure 4). Thus the ethanolic extract of Frullania dilatata showed considerably higher concentration of phenolics $\left(1600 \mathrm{~cm}^{-1}\right)$ while that of Dicranum scoparium much higher concentration of esters $\left(1712 \mathrm{~cm}^{-1}\right)$. In aqueous extracts higher concentration of phenolics was found in extracts of Marchantia polymorpha, Lophocolea heterophylla and Nowellia curvifolia. In general, the concentration of phenolics was higher in ethanolic extracts.

In all extracts, the proportion of carbohydrates was higher than that of other determined compounds, except for four liverwort species (Frullania dilatata, Lophocolea heterophylla, Marchantia polymorpha and Nowellia curvifolia); in these species, the proportion of phenols was the highest. In other species, phenols have been proved to be the second largest group of substances; the only exception was Plagiochila asplenioides, for which the second largest group was made up by amides (Table 2). Dicranum scoparium and Atrichum undulatum extracts differed by significant ester content. In other extracts ester bands were weak and in many samples even missed.

\section{Discussion}

In Latvia, folk medicine and ethnopharmacological traditions of using bryophytes virtually do not exist; nevertheless more than 550 species of bryophytes have been found growing in this country [16]. In our study, extracts of 20 bryophytes collected in Latvia were screened for antibacterial activity. Microbiological tests indicated that different bryophytes possess different influence on the 


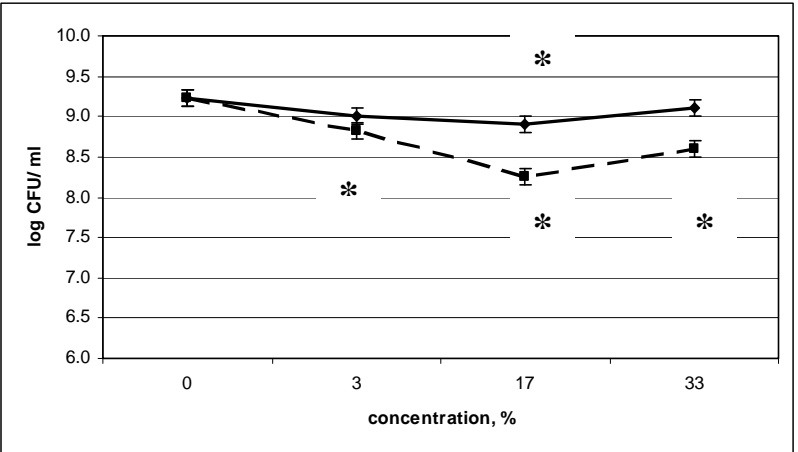

(a)

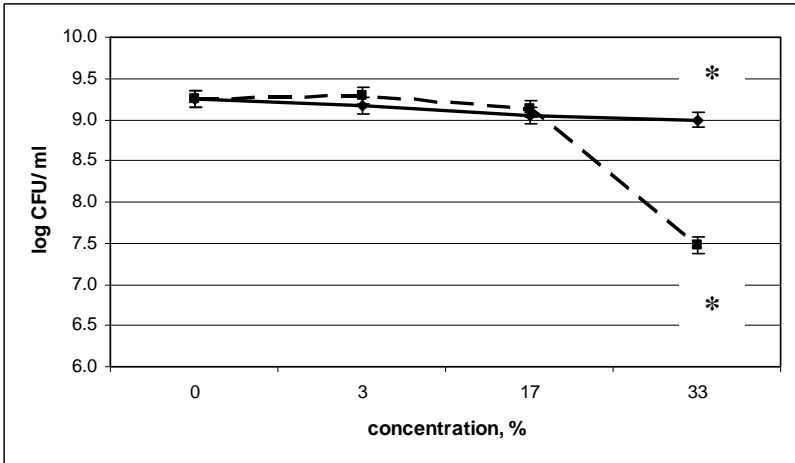

(c)

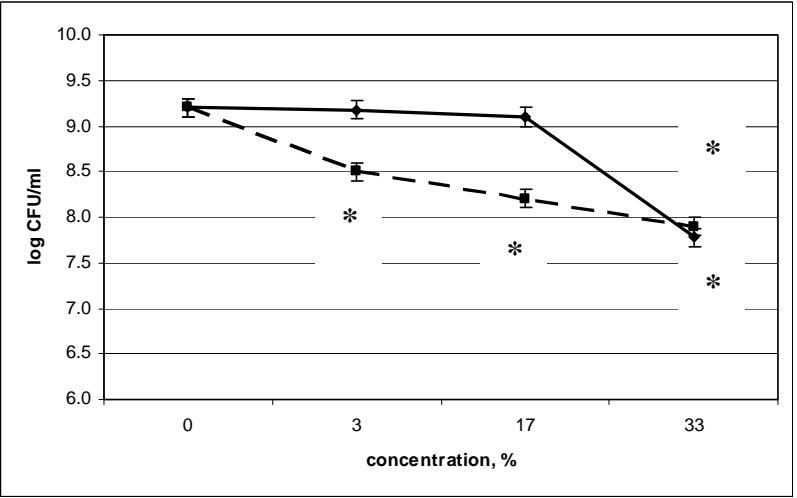

(e)

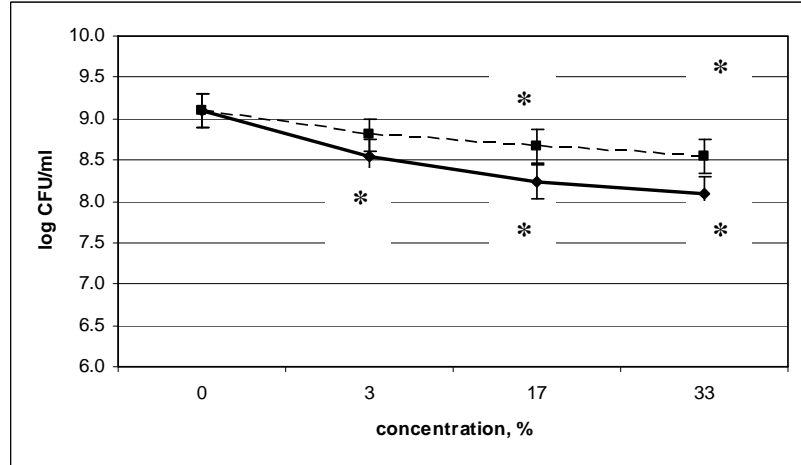

(g)

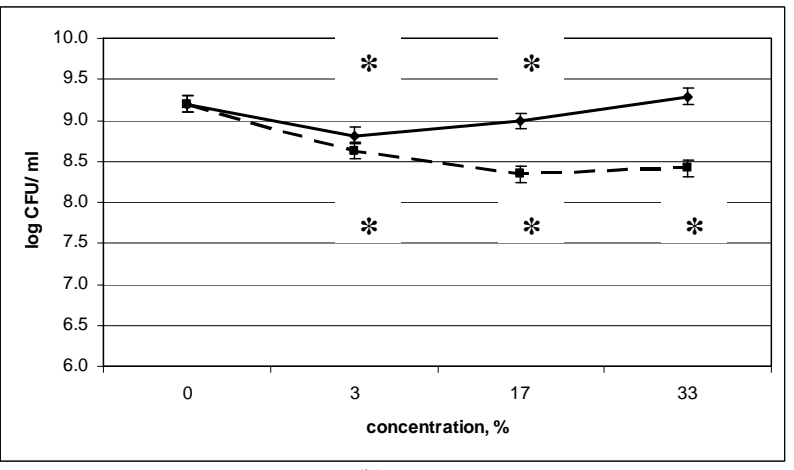

(b)

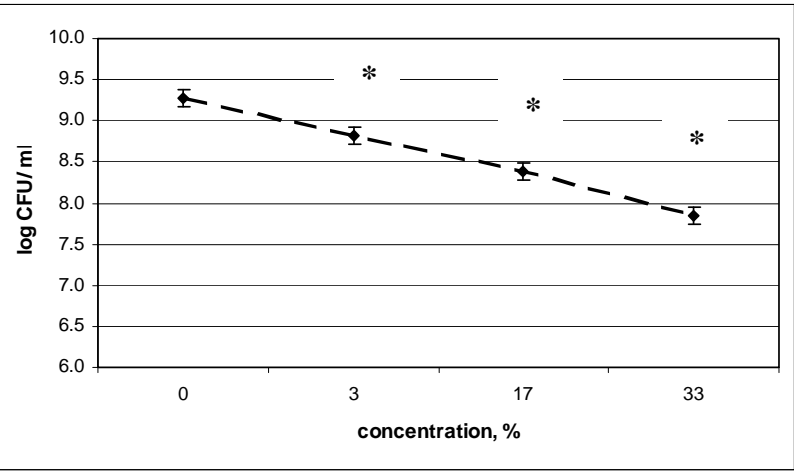

(d)

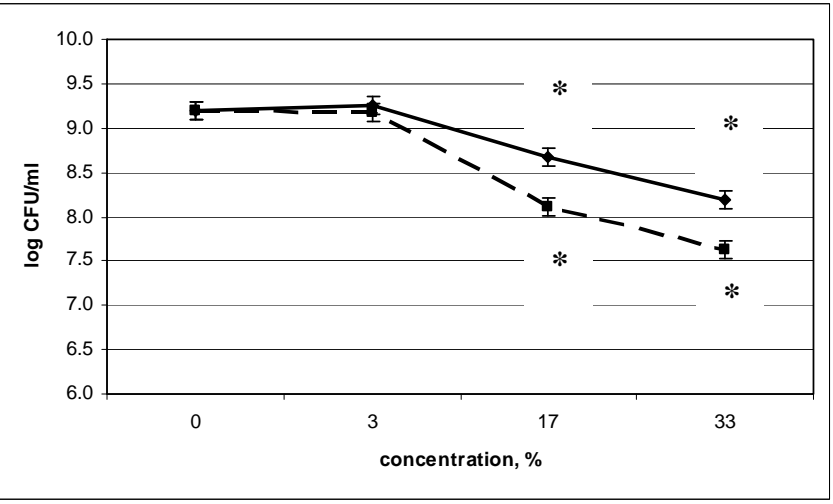

(f)

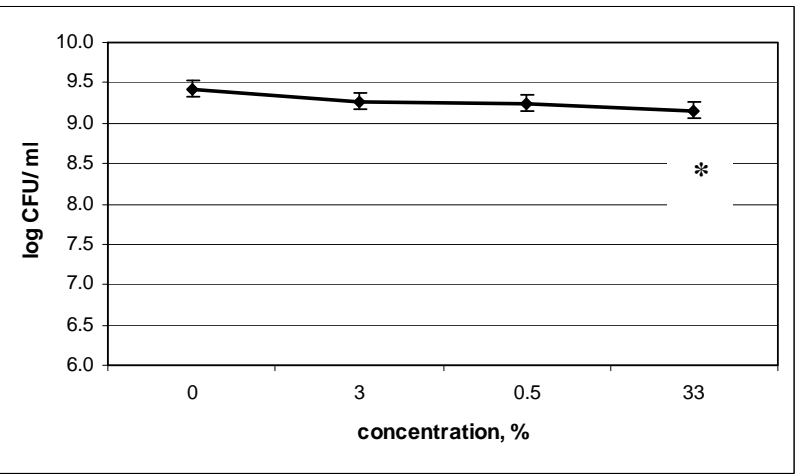

(h)

Figure 1. Inhibition of Staphylococcus aureus growth by mosses in dependence of the concentration of their aqueous or ethanolic extract. (a) Eurhynchium angustirete; (b) Rhytidiadelphus squarrosus; (c) Polytrichum commune; (d) Atrichum undulatum; (e) Dicranum scoparium; (f) Rhodobryum roseum; (g) Hylocomium splendens; (h) Fissidens taxifolius; aqueous extract; - - - ethanolic extract; ${ }^{*} P<0.05$ in comparison with control, without extract. 


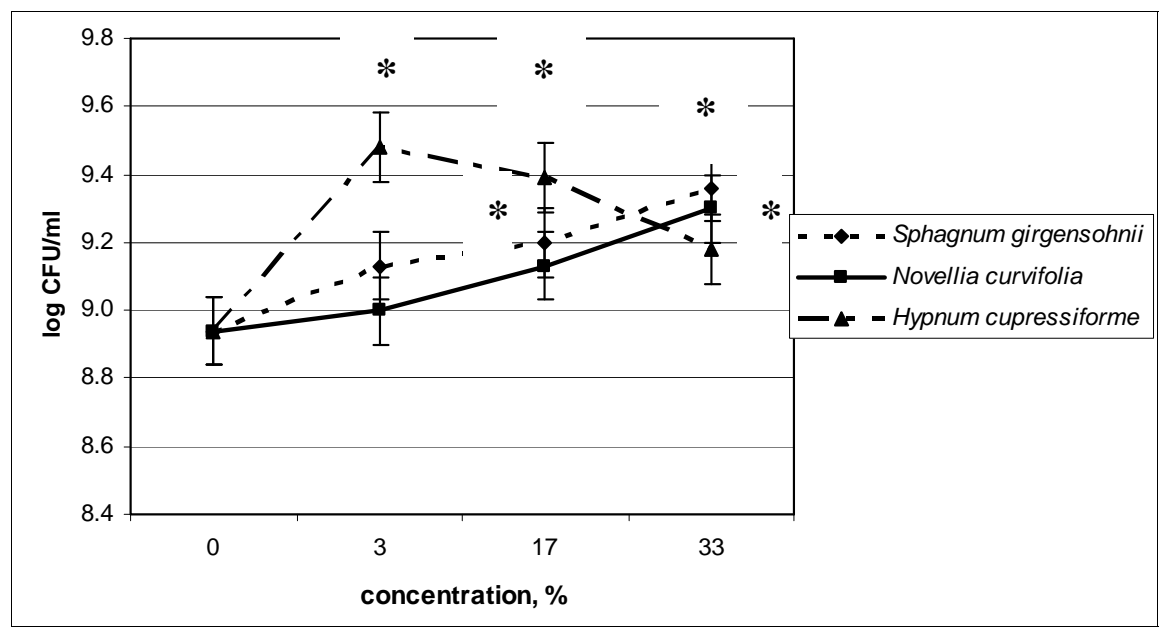

Figure 2. Stimulation of Staphylococcus aureus growth by three species of bryophytes in dependence of concentration of their aqueous extracts. ${ }^{*} P<0.05$ in comparison with control, without extract.

growth of microorganisms, from inhibition to stimulation.

$70 \%$ of bryophyte species demonstrated certain activity in relation to Staphylococcus aureus. $55 \%$ of the species showed a more or less pronounced antibacterial activity. $\mathrm{MIC}_{80}$ was achieved and therefore could be estimated for 10 extracts (Table 1). Bactericidal effect has not been found in any case.

Chi-square test showed that significantly more moss species had antibacterial properties in comparison to liverwort species (Table 2, $P<0.001$ ). Probably it was due to the fact that only for two liverwort species ethanolic extracts were studied instead of aqueous extracts. On the other hand, ethanolic extracts were studied for nine moss species.

In general, $73 \%$ of ethanolic extracts and $39 \%$ of aqueous extracts exhibited antibacterial activity against $S$. aureus. Ethanolic extracts exhibited also a higher degree of antimicrobial activity as compared with aqueous extracts with exception of Frullania dilatata and Hylocomium splendens, the aqueous extracts of these species showed higher antimicrobial activity than the ethanolic extracts (Table 1). In our experiments, the aqueous extract of Marchantia polymorpha did not influence the growth of $S$. aureus, although in literature data can be found about the antibacterial influence of this liverwort species on gram-positive bacteria among others [31]. This is also explainable by the type of extract. The ethanolic extracts of $M$. palmata have been described as having slightly higher antibacterial activity in comparison with the aqueous extracts [32]. It is known that one of characteristic features of Marchantiophyta, in difference from Bryophyta and Anthocerotophyta, is the presence of cellular oil bodies and production of a number of lipophilic terpenoids, aromatic compounds and acetogenins, several of which show biological activity including anti- bacterial and antifungal activities [4]. These oil bodies can be extracted with organic solvents.

The highest antimicrobial activity against $S$. aureus was shown by the ethanolic extract of Dicranum scoparium $\left(\mathrm{MIC}_{80} 3 \%\right.$ ) and aqueous extracts of Atrichum undulatum and Rhytidiadelphus squarrosus $\left(\mathrm{MIC}_{80}\right.$ of $7 \%$ for both species) (Table 1). The antibiotically active substances of Atrichum and Dicranum spp. are considered to be polyphenolic compounds [33]. In particular, flavonoids, including phenolic acids, are the main group of phenols obtained from mosses [34]. It is important that the antibacterial activity of aqueous extracts in our experiments was heat stable. This fact can lighten the work in case if any of the extracts would be introduced in future practice.

The interconnection between the antimicrobial activity and content of phenolics, esters, amides and/or carbohydrates was not estimated.

To the best of our knowledge, the antimicrobial activity of five of above mentioned bryophyte extracts has not been previously reported. For the first time, antimicrobial activity has been found for three moss species, Eurhynchium angustirete, Rhytidiadelphus squarrosus and Rhodobryum roseum, and for two liverwort species, Frullania dilatata and Lophocolea heterophylla, although in the genus Frullania, antifungal activity had been previously reported for the species F. muscicola [35] and antibacterial activity-for species $F$. nisquallensis [36]. Previously, the chemical composition of L. heterophylla had been investigated. Asakawa [5] believes it is unique, because this liverwort species contains monoterpene 2-methylisoborneol together with calamenene-type sesquiterpenes and eudesmanolides. Further research is needed to obtain information about correlation between chemical composition and antimicrobial activity of bryophyte species. 


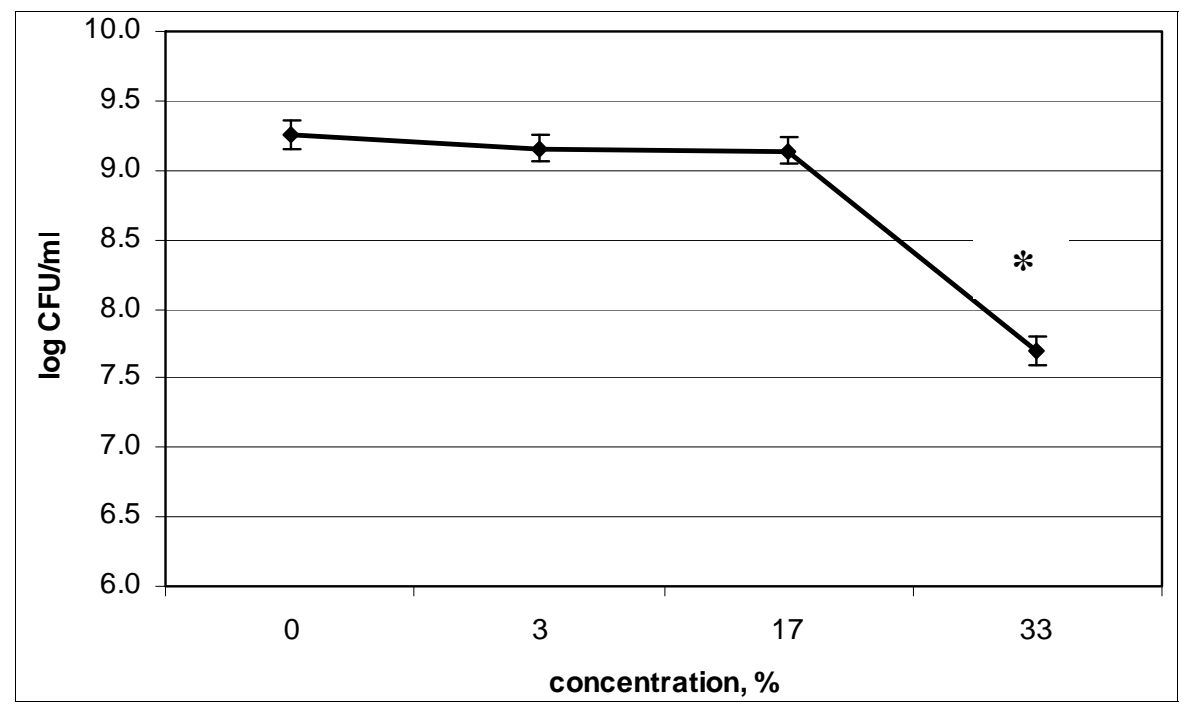

(a)

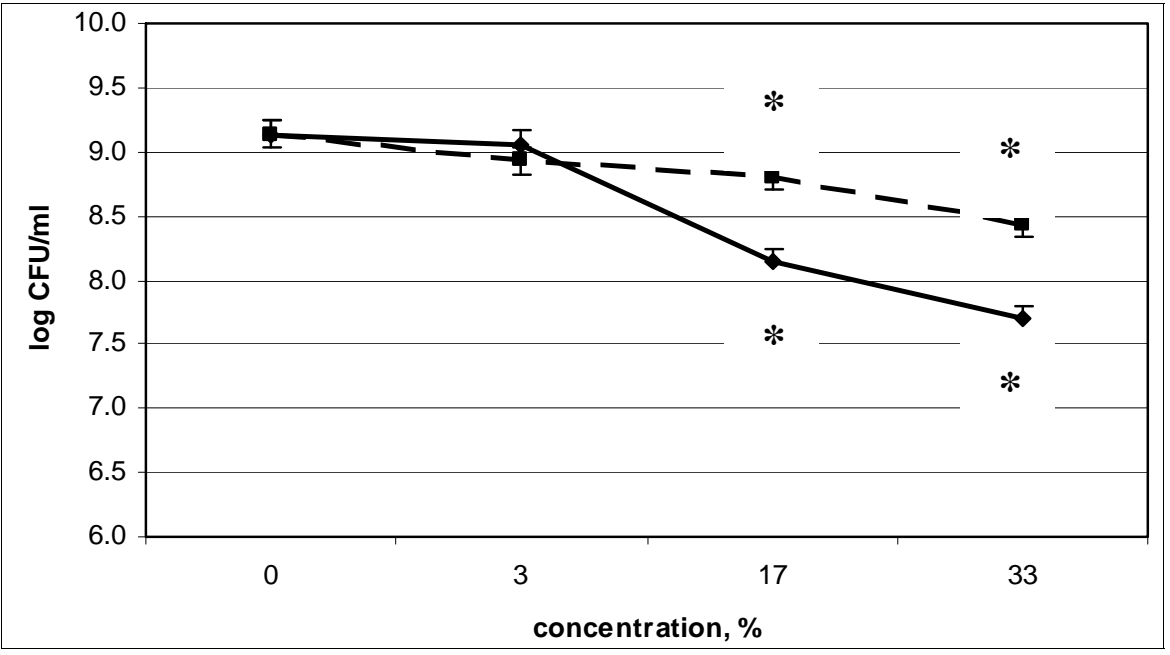

(b)

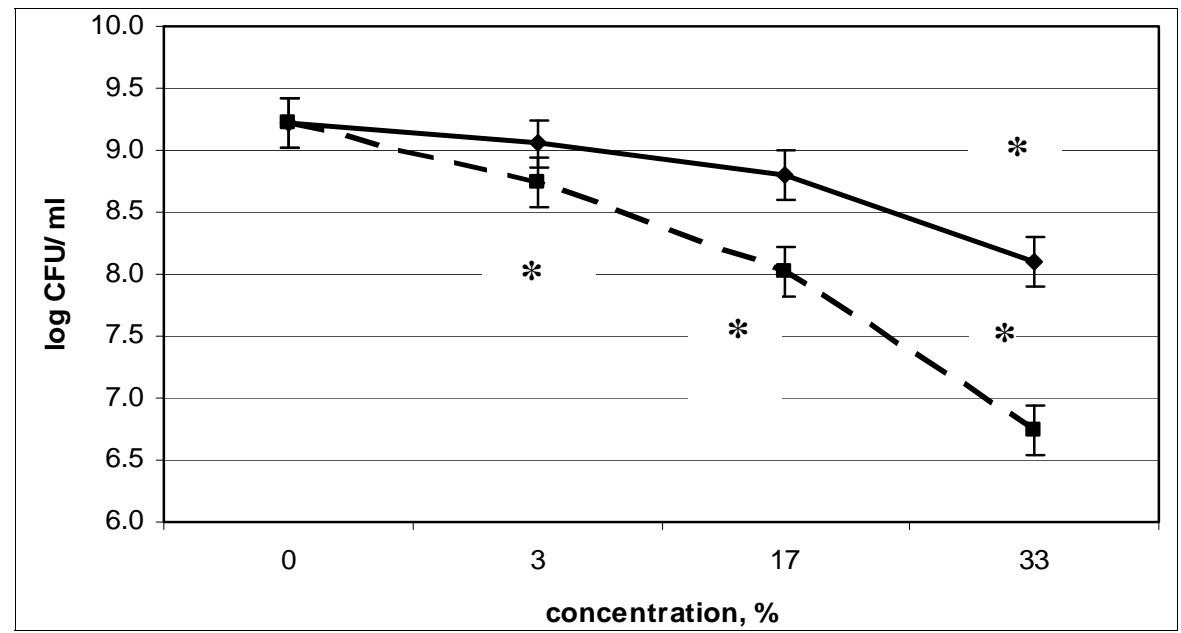

(c)

Figure 3. Inhibition of Staphylococcus aureus growth by liverworts in dependence of the concentration of their aqueous or ethanolic extract. (a) Ptilidium pulcherrinum; (b) Frullania dilatata; (c) Lophocolea heterophylla; — - aqueous extract; - - ethanolic extract; ${ }^{*} P<0.05$ in comparison with control, without extract. 


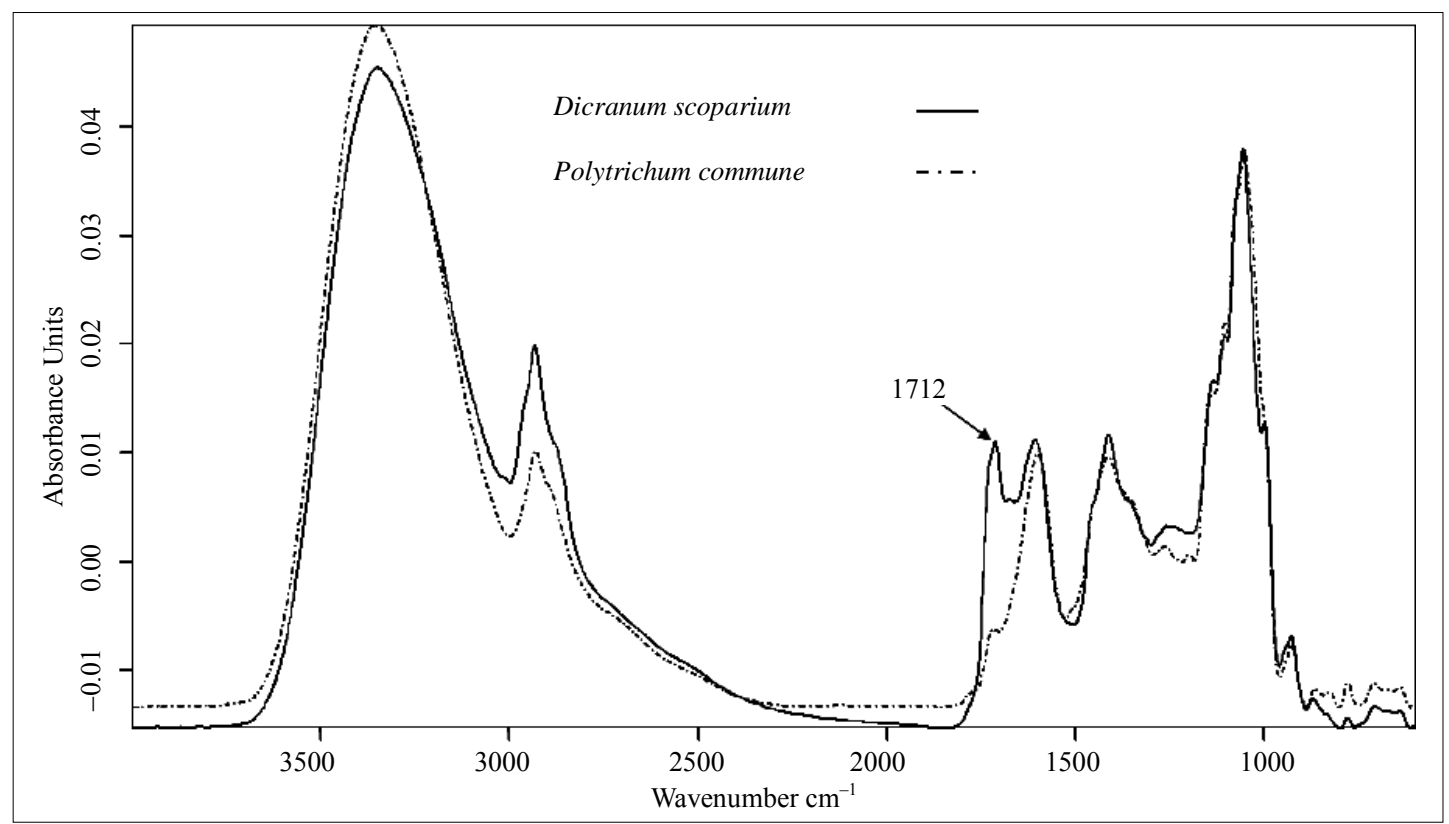

Figure 4. FT-IR absorption spectra of Dicranum scoparium and Polytrichum commune ethanolic extracts.

Table 2. Features of chemical composition of bryophytes extracts, expressed in relative units (FT-IR data).

\begin{tabular}{|c|c|c|c|c|c|c|c|c|}
\hline \multirow{2}{*}{ Species } & \multicolumn{2}{|c|}{ Amides } & \multicolumn{2}{|c|}{ Esters } & \multicolumn{2}{|c|}{ Phenolics } & \multicolumn{2}{|c|}{ Carbohydrates } \\
\hline & aqueous & ethanolic & aqueous & ethanolic & aqueous & ethanolic & aqueous & ethanolic \\
\hline \multicolumn{9}{|l|}{ Bryophyta } \\
\hline Atrichum undulatum & N.T. & 0.024 & N.T. & 0.013 & N.T. & 0.042 & N.T. & 0.069 \\
\hline Dicranum scoparium & N.T. & 0.022 & N.T. & 0.018 & N.T. & 0.030 & N.T. & 0.065 \\
\hline Eurhynchium angustirete & N.T. & 0.027 & N.T. & 0.007 & N.T. & 0.040 & N.T. & 0.081 \\
\hline Fissidens taxifolius & 0.016 & N.T. & 0.000 & N.T. & 0.024 & N.T. & 0.037 & N.T. \\
\hline Hylocomium splendens & 0.016 & N.T. & 0.000 & N.T. & 0.024 & N.T. & 0.043 & N.T. \\
\hline Hypnum cupressiforme & 0.015 & N.T. & 0.004 & N.T. & 0.028 & N.T. & 0.035 & N.T. \\
\hline Plagiomnium undulatum & N.T. & 0.031 & N.T. & 0.000 & N.T. & 0.051 & N.T. & 0.069 \\
\hline Polytrichum commune & N.T. & 0.025 & N.T. & 0.003 & N.T. & 0.038 & N.T. & 0.050 \\
\hline Rhodobryum roseum & 0.014 & 0.030 & 0.000 & 0.000 & 0.015 & 0.026 & 0.045 & 0.045 \\
\hline Rhytidiadelphus squarrosus & N.T. & 0.024 & N.T. & 0.005 & N.T. & 0.035 & N.T. & 0.066 \\
\hline Sphagnum girgensohnii & 0.014 & N.T. & 0.000 & N.T. & 0.024 & N.T. & 0.041 & N.T. \\
\hline \multicolumn{9}{|l|}{ Marchantiophyta } \\
\hline Frullania dilatata & N.T. & 0.034 & N.T. & 0.000 & N.T. & 0.067 & N.T. & 0.036 \\
\hline Lepidozia reptans & 0.015 & N.T. & 0.000 & N.T. & 0.023 & N.T. & 0.033 & N.T. \\
\hline Lophocolea heterophylla & 0.023 & 0.040 & 0.000 & 0.000 & 0.041 & 0.068 & 0.031 & 0.057 \\
\hline Marchantia polymorpha & 0.026 & N.T. & 0.000 & N.T. & 0.055 & N.T. & 0.028 & N.T. \\
\hline Nowellia curvifolia & 0.017 & N.T. & 0.000 & N.T. & 0.032 & N.T. & 0.030 & N.T. \\
\hline Plagiochila asplenioides & 0.014 & N.T. & 0.000 & N.T. & 0.013 & N.T. & 0.039 & N.T. \\
\hline Ptilidium pulcherrimum & 0.017 & N.T. & 0.000 & N.T. & 0.026 & N.T. & 0.040 & N.T. \\
\hline Radula complanata & 0.019 & N.T. & 0.000 & N.T. & 0.026 & N.T. & 0.040 & N.T. \\
\hline
\end{tabular}

N.T.: not tested. 


\section{Acknowledgements}

This study was supported by the European Regional Development Fund (ERDF) (2010/0295/2DP/2.1.1.1.0/10/ APIA/VIAA/134).

\section{REFERENCES}

[1] J. P. Frahm, "Biologie der Moose," Spektrum Verlag, Berlin, 2001.

[2] H. Ando and A. Matsuo, "Applied Bryology," In: J. Cramer, Ed., Advances in Bryology, Vol. 2, International Association of Bryologists, Berlin, 1984, pp. 133-224.

[3] E. L. Decker, G. Gorr and R. Reski, "Moss-An Innovative Tool for Protein Production," BIOforum Europe, No. 2, 2003, pp. 96-97.

[4] Y. Asakawa, "Liverworts-Potential Source of Medicinal Compounds," Current Pharmaceutical Design, Vol. 14, No. 29, 2008, pp. 3067-3088. doi: $10.2174 / 138161208786404272$

[5] Y. Asakawa, "Chemosystematics of the Hepaticae," Phytochemistry, Vol. 65, No. 6, 2004, pp. 623-669.

[6] Y. Asakawa, "Biologically Active Compounds from Bryophytes," Pure and Applied Chemistry, Vol. 79, No. 4, 2007, pp. 557-580. doi:10.1351/pac200779040557

[7] R. Castaldo-Cobianchi, S. Giordano, A. Basile and U. Violante, "Occurrence of Antibiotic Activity in Conocephalum conicum, Mnium undulatum and Leptodictyum riparium (Bryophyta)," Plant Biosystems, Vol. 122, No. 5, 1988, pp. 303-311.

[8] C. Borel, D. H. Welti, I. Fernandez and M. Colmenares, "Dicranin, an Antimicrobial and 15-Lipoxygenase Inhibitor from the Moss Dicranum scoparium," Journal of Natural Products, Vol. 56, No. 7, 1993, pp. 1071-1077. doi:10.1021/np50097a010

[9] E. Kamory, G. M. Keseru and B. Papp, "Isolation and Antibacterial Activity of Marchantin A, a Cyclic Bis(bibenzyl) Constituent of Hungarian Marchantia polymorpha," Planta Medica, Vol. 61, No. 4, 1995, pp. 387-388. doi:10.1055/s-2006-958116

[10] A. Basile, M. L. Vuotto, M. T. L. Ielpo, V. Moscatiello, L. Ricciardi, et al., "Antibacterial Activity in Rhynchostegium riparioides (Hedw.) Card. Extract (Bryophyta)," Phytotherapy Research, Vol. 12, No. S1, 1998, pp. S146S148.

[11] A. Sabovljevic, M. Sokovic, M. Sabovljevic and D. Grubisic, "Antimicrobial Activity of Bryum argenteum," Fitoterapia, Vol. 77, No. 2, 2006, pp. 144-145. doi:10.1016/j.fitote.2005.11.002

[12] A. Sabovljevic, M. Sokovic, J. Glamoclija, A. Ciric, M. Vujicic, et al., "Bio-Activities of Extracts from Some Axenically Farmed and Naturally Grown Bryophytes," Journal of Medicinal Plant Research, Vol. 5, No. 4, 2011, pp. 565-571.

[13] M. Veljic, M. Tarbuk, P. D. Marin, A. Ciric, M. Sokovic and M. Marin, "Antimicrobial Activity of Methanol Extracts of Mosses from Serbia," Pharmaceutical Biology,
Vol. 46, No. 12, 2008, pp. 871-875.

[14] M. Veljic, A. Djuric, M. Sokovic, A. Ciric, J. Glamoclija and P. D. Marin, "Antimicrobial Activity of Methanol Extracts of Fontinalis antipyretica, Hypnum cupressiforme and Ctenidium molluscum," Archives of Biological Science Belgrade, Vol. 61, No. 2, 2009, pp. 225-229.

[15] M. Veljic, A. Ciric, M. Sokolovic, P. Janackovic and P. D. Marin, "Antibacterial and Antifungal Activity of the Liverwort (Ptilidium pulcherrimum) Methanol Extract," Archives of Biological Science Belgrade, Vol. 62, No. 2, 2010, pp. 381-395.

[16] A. Abolina, "List of Bryophytes of Latvia," Latvijas Vegetacija, No. 3, 2001, pp. 47-87 (in Latvian).

[17] L. Soderstrom, E. Urmi and J. Vana, "Distribution of Hepaticae and Anthocerotae in Europe and Macaronesia," Lindbergia, Vol. 27, No. 1, 2002, pp. 3-47.

[18] L. Soderstrom, E. Urmi and J. Vana, "The Distribution of Hepaticae and Anthocerotae in Europe and Macaronesia. Update 1-427," Cryptogamie, Bryologie, Vol. 28, No. 4, 2007, pp. 299-350.

[19] M. O. Hill, N. Bell, M. A. Bruggeman-Nannenga, M. Brugues, M. J. Cano, et al., "An Annotated Checklist of the Mosses of Europe and Macaronesia," Journal of Bryology, Vol. 28, No. 3, 2006, pp. 198-267.

[20] A. Seneca and L. Soderstrom, "Sphagnophyta of Europe and Macaronesia: A Checklist with Distribution Data," Journal of Bryology, Vol. 31, No. 4, 2009, pp. 243-252. doi:10.1179/037366809X12499061230308

[21] A. J. E. Smith, "The Liverworts of Britain and Ireland," Cambridge University Press, Cambridge, 1996.

[22] A. J. E. Smith, "The Moss Flora of Britain and Ireland," Cambridge University Press, Cambridge, 1996.

[23] A. J. E. Smith, "The Moss Flora of Britain and Ireland," 2nd Edition, Cambridge University Press, Cambridge, 2004. doi:10.1017/CBO9780511541858

[24] M. S. Ignatov and E. A. Ignatova, "Moss Flora of the Middle European Russia, Vol. 1: Sphagnaceae-Hedwigiaceae," KMK Scientific Press Ltd., Moscow, 2003 (in Russian).

[25] M. S. Ignatov and E. A. Ignatova, "Moss Flora of the Middle European Russia, Vol. 2: Fontinaliaceae-Amblystegiaceae," KMK Scientific Press Ltd., Moscow, 2004 (in Russian).

[26] J. F. Acar and F. W. Goldstein, "Disc Susceptibility Test," In:V. Lorian, Ed., Antibiotics in Laboratory Medicine, 4th Edition, Williams \& Wilkins, Baltimore, 1996, pp. 1-51.

[27] F. Candan, M. Unlu, B. Tepe, D. Daferera, M. Polissiou, et al., "Antioxidant and Antimicrobial Activity of Essential Oil and Methanol Extracts of Achillea millefolium subsp. millefolium Afan. (Asteraceae)," Journal of Ethnopharmacology, Vol. 87, No. 2-3, 2003, pp. 215-220. doi:10.1016/S0378-8741(03)00149-1

[28] S. Qaiyumi, "Macro- and Microdilution Methods of Antimicrobial Susceptibility Testing," In: R. Schwalbe, L. Steele-Moore and A. C. Goodwin, Eds., Antimicrobial Susceptibility Testing Protocols, CRC Press, Boca Raton, 
London, New York, 2007, pp. 75-79. doi:10.1201/9781420014495.ch4

[29] M. D. Guillen and N. Cabo, "Some of the Most Significant Changes in the Fourier Transform Infrared Spectra of Edible Oils under Oxidative Conditions," Journal of the Science of Food and Agriculture, Vol. 80, No. 14, 2000, pp. 2028-2036.

[30] N. Vlachos, Y. Skopelitis, M. Psaroudaki, V. Konstantinidou, A. Chatzilazarou and E. Tegou, "Applications of Fourier Transform-Infrared Spectroscopy to Edible Oils," Analytica Chimica Acta, Vol. 573-574, 2006, pp. 459-465. doi:10.1016/j.aca.2006.05.034

[31] Y. Asakawa, "Highlights in Phytochemistry of Hepaticae-Biologically Active Terpenoids and Aromatic Compounds," Pure and Applied Chemistry, Vol. 66, No. 10-11, 1994, pp. 2193-2196. doi:10.1351/pac199466102193

[32] R. Khanam, B. L. Chaudhary, S. Khanam and P. Kumar, "Antibacterial Activity of Marchantia palmata Nees,"
Asian Journal of Biochemical and Pharmaceutical Research, Vol. 1, No. 2, 2011, pp. 27-36.

[33] J. A. McCleary and D. L. Walkington, "Mosses and Antibiosis," Revue Bryologique et Lichenologique, Vol. 34, 1966, pp. 309-314.

[34] A. Basile, S. Giordano, J. A. Lopez-Saez and R. C. Cobianchi, "Antibacterial Activity of Pure Flavonoids Isolated from Mosses," Phytochemistry, Vol. 52, No. 8, 1999, pp. 1479-1482.

[35] H. X. Lou, G. Y. Li and F. Q. Wang, “A Cytotoxic Diterpenoid and Antifungal Phenolic Compounds from Frullania muscicola Steph.," Journal of Asian Natural Products Research, Vol. 4, No. 2, 2002, pp. 87-94. doi:10.1080/10286020290027353

[36] M. D. Russel, "Antibiotic Activity of Extracts from some Bryophytes in South Western British Columbia," Medical Student Journal of Australia, Vol. 2, No. 1, 2010, pp. 914. 